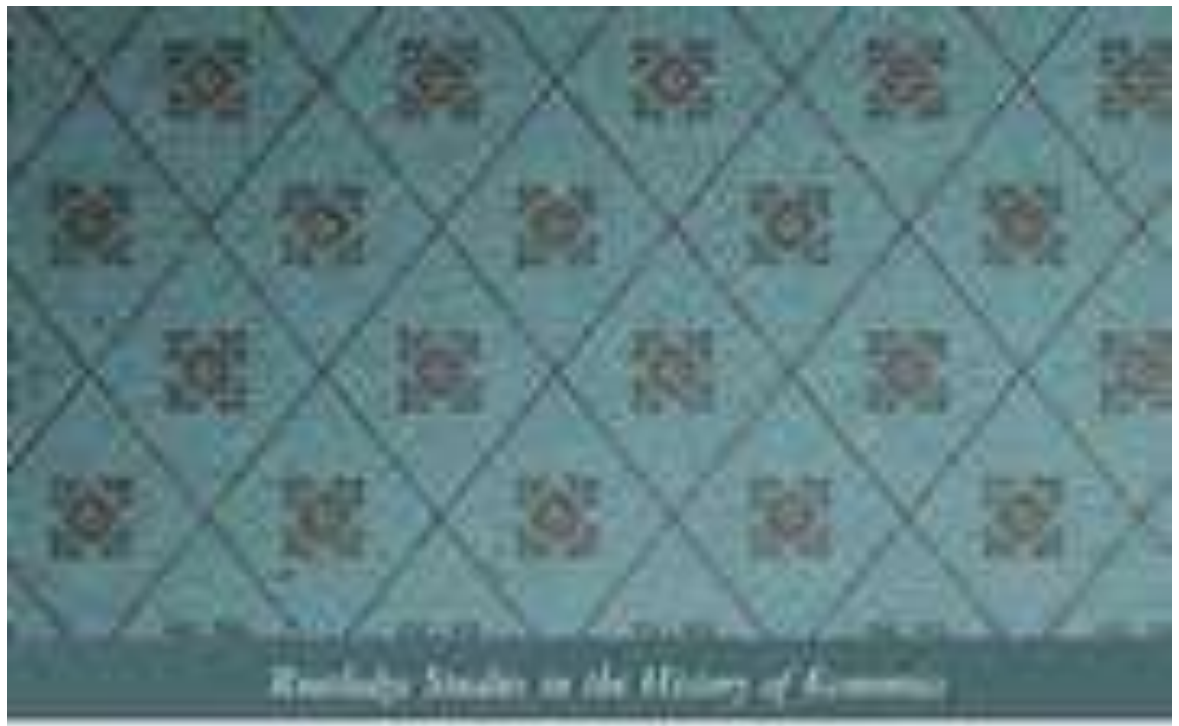

\title{
DAVID RICARDO. AN INTELLECTUAL BIOGRAPHY
}

Sritio fremastin

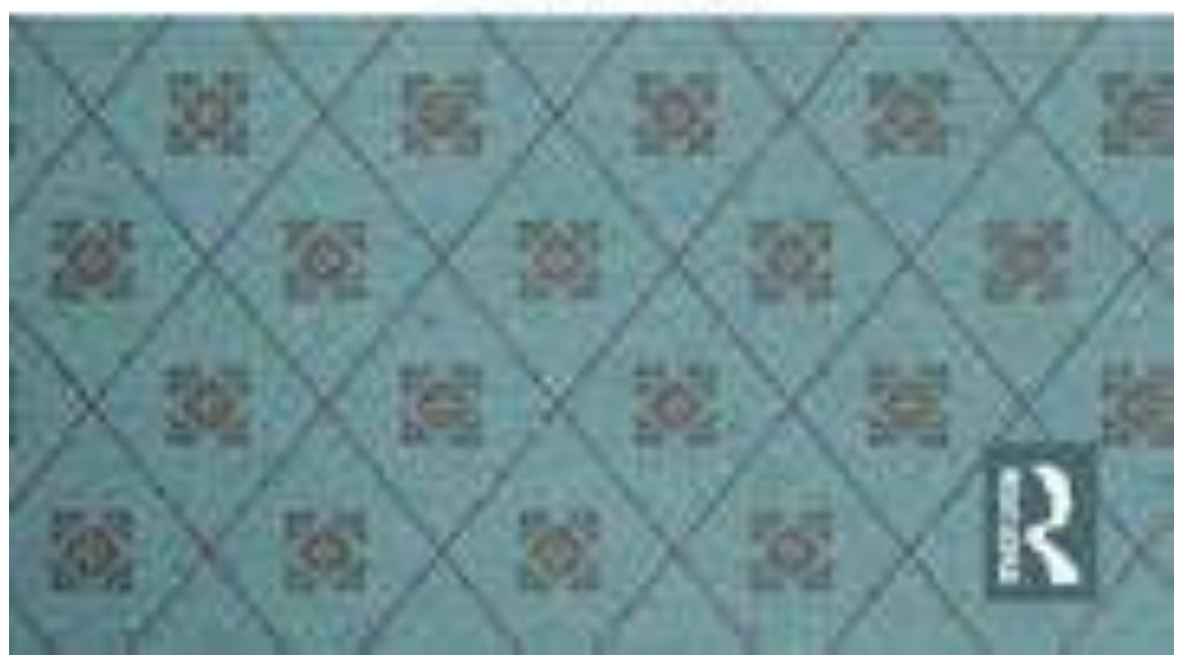




\section{David Ricardo. An}

\section{Intellectual Biography}

David Ricardo has been acclaimed - or vilified - for merits he would never have dreamt of, or sins for which he was entirely innocent. Entrenched mythology labels him as a utilitarian economist, an enemy of the working class, an impractical theorist, a scientist with 'no philosophy at all' and the author of a formalist methodological revolution. Exploring a middle ground between theory and biography, this book explores the formative intellectual encounters of a man who came to economic studies via other experiences, thus bridging the gap between the historical Ricardo and the economist's Ricardo.

The chapters undertake a thorough analysis of Ricardo's writings in their context, asking who was speaking, what audience was being addressed, with what communicative intentions, using what kind of lexicon and communicative conventions, and starting with what shared knowledge. The work opens in presenting the different religious communities with which Ricardo was in touch. It goes on to describe his education in the leading science of the time geology - before he turned to the study of political economy. Another chapter discusses five 'philosophers' - students of logic, ethics and politics - with whom he was in touch. From correspondence, manuscripts and publications, the closing chapters reconstruct, firstly, Ricardo's ideas on scientific method, the limits of the 'abstract science' and its application, secondly, his ideas on ethics and politics and their impact on strategies for improving the condition of the working class. This book sheds new light on Ricardian economics, providing an invaluable service to readers of economic methodology, philosophy of economics, the history of economic thought, political thought and philosophy.

Sergio Cremaschi is a former Reader of Moral Philosophy at the 'Amedeo Avogadro' University at Vercelli, Italy. 


\section{Routledge Studies in the History of Economics}

John Locke and the Bank of England

Claude Roche

Poverty in Contemporary Economic Thought

Edited by Mats Lundahl, Daniel Rauhut and Neelambar Hatti

Thomas Aquinas and the Civil Economy Tradition

The Mediterranean Spirit of Capitalism

Paolo Santori

The Macroeconomics of Malthus

John Pullen

Competition, Value and Distribution in Classical Economics

Studies in Long-Period Analysis

Heinz D. Kurz and Neri Salvadori

David Ricardo. An Intellectual Biography

Sergio Cremaschi

Humanity and Nature in Economic Thought

Searching for the Organic Origins of the Economy

Edited by Gábor Bíró

European and Chinese Histories of Economic Thought

Theories and Images of Good Governance

Edited by Iwo Amelung and Bertram Schefold

For more information about this series, please visit www.routledge.com/

series/SE0341 


\section{David Ricardo. An}

\section{Intellectual Biography}

\section{Sergio Cremaschi}

First published 2022

by Routledge

2 Park Square, Milton Park, Abingdon, Oxon OX14 4RN

and by Routledge

605 Third Avenue, New York, NY 10158

Routledge is an imprint of the Taylor \& Francis Group, an informa business

(C) 2022 Sergio Cremaschi

The right of Sergio Cremaschi to be identified as author of this work has been asserted by him in accordance with sections 77 and 78 of the Copyright, Designs and Patents Act 1988.

All rights reserved. No part of this book may be reprinted or reproduced or utilised in any form or by any electronic, mechanical, or other means, now known or hereafter invented, including photocopying and recording, or in any information storage or retrieval system, without permission in writing from the publishers. Trademark notice: Product or corporate names may be trademarks or registered trademarks, and are used only for identification and explanation without intent to infringe.

British Library Cataloguing-in-Publication Data

A catalogue record for this book is available from the British Library Library of Congress Cataloging-in-Publication Data

A catalog record has been requested for this book

ISBN: 978-0-367-75345-0 (hbk)

ISBN: 978-0-367-75347-4 (pbk)

ISBN: 978-1-003-16210-0 (ebk)

DOI: $10.4324 / 9781003162100$

Typeset in Bembo

by codeMantra 


\section{Contents}

About the author ix

Preface: Science, logic, ethics and theology in Ricardo's

intellectual biography xi

1 Ricardo's Sepharad 1

Twenty-one years in Ricardo's life 1

Anglo-Judaism from 1600 to 17933

Echoes from the Haskalah 5

Ricardo's education 5

Partial conclusions: the importance of being an outsider 13

2 Ricardo's encounter with the Quakers 18

The Society of Friends 18

British Quakerism at the time of the French Revolution 20

The impossible marriage of a Jew with a Quaker 21

Ricardo's Quaker relations 25

Ricardo's involvement in a Quaker secession 26

Partial conclusions: the importance of being a husband 27

3 Ricardo's encounter with the Unitarians 29

Scripture and reason 29

Ricardo's 'conversion' 31

Robert Aspland, the missionary to the Jews 33

Thomas Belsham, the Biblical scholar 34

James Lindsay, the campaigner for Toleration 38

John Bowring and Thomas Smith 40

Partial conclusions: the importance of being a Dissenter 41 
vi Contents

4 Ricardo's encounter with geologists 46

Ricardo's higher education 46

The London Institution 50

Chemistry after the phlogiston controversy 51

Geology after the catastrophism-uniformitarianism controversy 52

Richard Kirwan 53

The Geological Society of London 56

Controversies in geology: logic, definitions, and causality 57

From chemistry and geology to political economy 58

Partial conclusions: the importance of a scientific education 62

5 Ricardo's encounter with philosophers and political economists 66

Francis Horner and the Scottish philosophy 66

Jeremy Bentham and the philosophic radicals 69

James Mill, between Scottish philosophy and Benthamism 71

Thomas Robert Malthus and the Cambridge philosophy 76

Thomas Belsham and the Hartley-Priestley philosophy 79

Jean-Baptiste Say and the idéologie 86

Partial conclusions: a high station among philosophers 88

6 Ricardo on logic and political economy 94

Ricardian rhetoric 94

Language and definitions 98

Laws and causes 103

Permanent causes and natural magnitudes 107

Strong cases 109

The redundancy of utility 112

Ricardian logic and scientific practice 117

Ricardian logic and policy advice 122

Partial conclusions: a science without an art 124

7 Ricardo on ethics and political economy 130

Moral impressions and the rational pursuit of happiness 130

Just war 140

Penal law and private morality 142

Slavery 143

Unlimited toleration 143

Good government 146

Ethics and the uses of political economy 152

The miscarriage of all social theodicies 158

Partial conclusions: neither a utilitarian nor theological optimist 166 
Contents vii

Conclusions: a man from another planet 172

Appendix 175

The Christian Reformer: text of the Christians' Petition 175

The Christian Reformer \& The Monthly Repository:

presentation of the Christians' Petition in the House of Commons

and the House of the Lords 179

The Sunday Times: Daniel Whittle Harvey's obituary 179

The Morning Chronicle: Mill's Letter to the Editor 183

The Monthly Repository: obituary 184

The Gentlemen’s Magazine: obituary 185

The Penny Cyclopaedia: George Porter's entry 186

Index 189 


\section{About the author}

Sergio Cremaschi (Bergamo 1949), 'Dottore in Filosofia' from the Catholic University, Milan in 1971, spent two years working in Somalia as a preparatory schoolteacher, was a research fellow at the Catholic University and Venice University and senior lecturer at the Catholic University. He was Reader of Philosophy of Religion at Ferrara University, then of Moral Philosophy at Turin University and the 'Amedeo Avogadro' University at Vercelli. He was a visiting fellow or lecturer at the New School for Social Research, New York, the Hebrew University, Jerusalem, Aarhus University, Denmark, Nuffield College, Oxford, the University of Málaga. He has published on ethics and the history and philosophy of economics. He retired in 2014. 


\section{Preface}

\section{Science, logic, ethics and theology in}

\section{Ricardo's intellectual biography}

This book is a contextual reconstruction of an economist's intellectual biography. The purpose is to look where others did not, due to such factors as inapt modernisation, proneness to accept received views, constraints created by boundaries between disciplines and historiographic mythology. The intent is to buy intellectual history, not in bulk but in retail. This implies looking at the cotext whenever the text is silent and at the context to make sense of what the text says or omits to say; it implies screening out what the text may not mean from what it may mean, reading utterances going beyond their literal meaning to seek out the speaker's communicative intentions, original audience and knowledge shared with that audience. Besides, it implies looking at the history of economic thought through spectacles different from the economist's, at the history of political ideas without reducing it programmatically to an appendix of the history of economic thought, at the history of ethics as the hotbed where the economic theory was sprouting and at the history of religion without secularist prejudice.

Sraffa's edition is still the starting point. He made an exceptionally meticulous job of it, despite not being a historian but rather an economist on loan to history. Yet, just like anyone else's, his personal history and theoretical approach carried a pre-comprehension that led to him emphasising some aspects and downplaying others. Thus a few chapters in the book try to cover blanks in Sraffa's reconstruction, including examples such as the story of the Italian liberal rabbi who, even before Ricardo was born, attempted to give a new start to London's Sephardic community; women intellectuals in the Delvalle-Ricardo family; the birth of the new magmatic science of geology; Unitarianism with its rationalist and socially committed message; and Ricardo's philosophical reading.

The reading of sources may be richer now than it was for our predecessors, but the merit is not ours. We are people of average stature standing precariously on the shoulders of giants. Dangerous though it may be for both our stability and the giants' backbones, coming after Schumpeter, Sraffa and Hollander gives us a broader perspective than any giant or person of above-average height could ever imagine. The attempt to detect real-world influences, sources, addressees and opponents may emancipate us from mental slavery to long-dead polemicists. 
xii Preface

It will certainly help to avoid mythological reconstructions such as Halévy's Benthamite Ricardo, Stigler's unphilosophical Ricardo and Hutchison's Millian Ricardo. A century ago, under the sway of watered-down Hegelianism, intellectual historians used to believe that their work was done once they had detected one idea formulated by an author in another before him. It was a search for causes instead of reasons, or the construction of Biblical genealogies, like Bentham begot Mill and Mill begot Ricardo, Descartes begot the Physiocrats and the Physiocrats begot Ricardo or - proceeding in the opposite direction - the neoclassical begot modern economic science and Ricardo must have carried the genes of neoclassical theory. Intellectual history is not a quest for cause-effect relationships and Michelangelo's Giudizio Universale was no more an effect of the counter-Reformation than was Ricardo's economic theory an effect of the Industrial Revolution.

Besides, intellectual historians may dream that an author was influenced by another one merely because he was later raised to greater fame while being comparatively unknown at the time under discussion. Sometimes they read an implicit quote into a text because they forget that the same word has a different meaning in a different context. They may read documents in translation and forget that one word's shades of meaning in their own language are irrelevant when it stands for a Latin, Greek or Hebrew word. More often they may read documents in eighteenth-century English and take it for granted that words had the same shades of meaning or showed up in the same contexts as now. On other occasions, they may strive to stretch meanings of sentences to fit everything an author wrote to a system they assume he had in mind because they are prey to the myth of coherence: that whatever an author says reveals a system of ideas hidden in his mind. They often tend to read what an author said as being addressed to us with the intention of informing us of facts. However, when Ricardo complained about his neglected education to Mill, he was not informing us but expressing respect for Mill's education at a prestigious university and regret for having been excluded from such an opportunity himself. When he told Mary Edgeworth that he had been sent to Amsterdam to learn Dutch, French and Spanish but had hardly learnt anything he was not informing us, he was shielding himself from an Anglo-Irish aristocrat's prying curiosity vis-à-vis such an exotic bird as a Jew.

There are multiple reasons for the existence of opposing interpretations and misinterpretations in Ricardo scholarship. One is the comparative scarcity of documents, another is reticence by primary sources caused by a desire not to fuel English-chauvinist prejudice vis-à-vis a 'migrant', and a third one is the ballast of past attacks or hagiography. Layers of interpretations encrusted in the text may have done the rest, and the tendency to read sources naively and overlook contexts gives the coup de grace. Stories of 'influences' by Descartes, the Physiocrats, Bentham, Mill and - as if it were not enough - Dugald Stewart are part of the story together with the specular picture of the first Metaphysikfrei economist whose busy mind made no room for philosophy. 
More than giving wrong answers, speculations about Ricardo's true philosophy, or lack of philosophy, answer the wrong kind of questions. The relationship between Ricardian economics and his intellectual outlook should be interpreted neither as the opposition of science to philosophy (Schumpeter, Hutchison and Stigler) nor as the dependence of science on one philosophy (Halévy). This relationship developed as a process through which distinct intellectual experiences equipped Ricardo with suggestions whereby he selected what he deemed useful to clarify his positive work or defend it from criticism. The owl of Minerva, as birdwatchers know, comes out at dusk. There was no Ricardian logic in 1811 to inspire his search for 'principles' that - as he wrote to Malthus on 17 April 1815 - could account 'for all the phenomena in an easy, natural manner' without getting lost in a 'labyrinth of difficulties' (Works 6, p. 214). Instead of schooling in one philosophy, Ricardo's equipment with logical, linguistic, epistemological, ethical and political ideas came from intellectual do-it-yourself. In order to respond to critics' objections he used material from several sources, a use that was not naive eclecticism but a search for arguments to fight what he felt to be delusory or ill-defined entities. His weapons came from an arsenal incompatible with epistemological realism, Cartesian rationalism or common-sense realism but bearing family resemblances with the Geological Society's legacy, Priestley and Belsham's epistemology and the postscepticism of Adam Smith.

The author conducted part of the work during a stay at Nuffield College, Oxford in 2013, which was made possible by a Jemolo Fellowship. He is grateful to the Bodleian Library, the British Library, Harry Manchester College Library, the Fondazione Einaudi, Turin, and Milan Catholic University and State University libraries. He presented the first draft of a chapter at the 1999 ESHET Meeting in Valencia, others at the Conference of the International Society for Utilitarian Studies, Lisbon, 2003, the 2014 STOREP Conference in Bergamo, the 2018 ESHET Conference in Madrid, the International Conference on Economic Philosophy, Lyon, 2018, the 2018 STOREP Conference in Piacenza, the 2019 STOREP in Genova, the Conference on James Mill and John Stuart Mill/Classical Political Economy, Kyoto, 2019. The author is grateful to the discussants at these conferences, Nathalie Sigot, Andrea Salanti, Ghislain Deleplace, Yuji Sato. The author is also grateful to Maria Luisa Pesante, Salim Rashid, Antony Waterman, Arnold Heertje, Gilbert Faccarello, Heinz Kurz, Neri Salvadori, Richard Allen, Wilfried Parys, Emanuele Levi Mortera and Ryan Walter for sparing him mistakes. Finally, two friends played an essential role in the birth of this book: Marcelo Dascal, who worked with the present author on the controversy between Malthus and Ricardo, and Pier Luigi Porta, who introduced him to Ricardo scholarship. Daphne Hughes has patiently eliminated from this book misprints, spelling mistakes and English usage infelicities. All that is left, of these and others blemishes, belongs to the author. 
xiv Preface

Chapter 7 contains materials from the following articles: 'Ricardo and the Utilitarians', The European Journal of the History of Economic Thought, vol. 11 (2004), no. 3 pp. 377403. DOI: 10.1080/0967256042000246476; 'Theological themes in Ricardo's papers and correspondence', The European Journal of the History of Economic Thought, vol. 24 (2017), no. 4, pp. 784-808. DOI: 10.1080/09672567.2017.1315954. Unless a translation appears in the bibliography, quotes from languages different from English are the author's translation. Throughout the text and references, Works stands for Ricardo, D 1951- 1973, The Works and Correspondence of David Ricardo, P Sraffa with the collaboration of MH Dobb (eds), Cambridge University Press, Cambridge. Published works, manuscript notes and speeches are listed in bibliographies. Reference to correspondence and evidence is made by citing volume and page of the Sraffa Edition. Thus, Works 6, p. 33 stands for The Works and Correspondence of David Ricardo, vol. 6, p. 33.

\section{Abstracts}

\section{Ricardo's Sepharad}

This chapter examines the first 21 years of his life, when he was a child in a London Sephardi household and, from the age of 13, a member of the Bevis Marks congregation. Given the scarcity of primary sources, the chapter adds something to the accounts available. First, it contends that we may learn something more about Ricardo's formative years and his religious and moral education than Sraffa and other biographers felt able to do with the scant documents available. Second, it contends that Ricardo's Sephardi background is essential to account for his moral and political commitments, particularly his ideas on toleration, and to understand the intellectual experiences he had and the motivations he acquired.

The chapter tries to perform a 'thick' reading of reticent utterances by Ricardo and other sources in the light of their co-text and context. The chapter interprets what they meant, whom they were addressing and what they wanted not to disclose to their audience. It conducts such thick reading by summarising first the problems with interpretation of sources on Ricardo's biography, secondly illustrating the history of the London Sephardi community until Ricardo's time, and finally reconstructing the context of Ricardo's education.

\section{Keywords}

Religion; Anglo-Judaism; Jewish Education and Schools; Spanish Language; Amsterdam 


\section{Ricardo's encounter with the Quakers}

This chapter illustrates what English Quakerism was at the end of the eighteenth century and the moral and intellectual assets this vibrating community granted its members and ventures into conjectures about the kind of contacts he may have had with Quaker milieus.

It illustrates the circumstances of Ricardo's marriage with a Quaker and the ensuing break with his religious community that left him in a religious no man's land. The chapter suggests that he became for a time a fellow traveller of Quakerism, and how this was not an exceptional event in his time and place, when a significant percentage of the Sephardi youngest generation, including a few among Ricardo siblings, severed ties with their community primarily through mixed marriage.

It argues that his acquaintance with Quakerism had, arguably, some role in shaping his political commitments and his views on toleration and philanthropic enterprises. The chapter adds evidence to the effect that his Quaker acquaintances had a role in shaping his intellectual interests, particularly encouraging him in the study of some areas of natural science, namely geology, mineralogy and chemistry.

\section{Keywords}

Religion; Quakerism; Toleration; Philanthropy; Mixed Marriages in Eighteenth-Century Britain

\section{Ricardo's encounter with the Unitarians}

This chapter collects overlooked evidence concerning Ricardo's adhesion to Unitarianism, showing how this was not an isolated event but part of a flux of adhesions, after a conflict between traditionalist and liberals, by Quakers who felt that Unitarianism was the closest approximation to the original Quaker spirit. Then the chapter examines elucubrations on Ricardo's Atheism, proving that no evidence whatsoever exists in their favour. The chapter concludes that there is no proof that Ricardo was either an agnostic or an atheist. The facts are that he was just a Sephardi convert like others; he converted to Unitarianism, which implied a less traumatic break with his origins than adhesion to the established Church; and he adhered to what looked then as the only available organised form of 'rational belief'.

\section{Keywords}

Religion; Unitarianism; Theology; Theodicy; Toleration; Philanthropy; Science 


\section{Ricardo's encounter with geologists}

This chapter revises available biographical evidence about Ricardo's family and the kind of education he received. Evidence concerning Ricardo's early interest in the natural sciences, considered by Sraffa to have had a more profound impact on Ricardo's mind than Benthamite philosophy, is collected and interpreted. It discusses the circumstance that geology was the most innovative science of the time because of its recent discoveries and their impact on religious issues such as the Creation of the world and the Bible's trustworthiness. It reconstructs the contents of a book for boys on mineralogy by one of Ricardo's cousins. It lists Ricardo's contacts at the Geological Society and ideas on scientific method circulating among geologists. It ends with the suggestion that, when historians of economic thought have believed it proper to try to take a trans-disciplinary look at the history of economic science, they have bought the history of science wholesale and drawn comparisons between Newtonian Astronomy and classical political economy. However, both political economy and geology date their origins at about the same time. Ricardo's contacts are reconstructed, including Francis Horner, whom he first met at the Geological Society and was the first source of encouragement to write on economic subjects.

\section{Keywords}

Chemistry; Mineralogy; Geology; British Scientific Societies; Geology and Theological Controversy; Geology and the Scientific Method

\section{Ricardo's encounter with philosophers and political economists}

This chapter discusses intellectual partnerships Ricardo established from the time he started cultivating economic studies. It discusses Ricardo's meeting with Francis Horner at the Geological Society and its impact on the beginning of his career in political economy. It discusses the relationship with Belsham and argues possible familiarity on Ricardo's side with topics from the Hartley-Priestley philosophy in language, epistemology, ethics and politics. It reconstructs the origins of the myth of Ricardo's dependence on Bentham through Mill, examines their shared political commitments and reconstructs Ricardo's increasingly critical attitude to Mill in ethics and politics and his master-to-pupil attitude to Mill in economic subjects. Then it offers an overview of the controversy with Malthus, highlighting the strong effects it had on Ricardo's line of enquiry. A similar overview is offered of the correspondence with Say, highlighting some influence exerted by Say in a first phase and the deadlock into which the correspondence was trapped because of mutual misunderstanding on the topic of utility and value.

\section{Keywords}

Newtonianism; Scottish Philosophy; Hartley-Priestley Philosophy; Benthamite Philosophy 


\section{Ricardo on logic and political economy}

This chapter illustrates how Ricardo's 'cast of mind' resulted from several influences absorbed at distinct phases in his intellectual evolution. In logic and epistemology, he owed virtually nothing to Bentham and Mill. He may have learnt philosophical ideas from discussions about Geology, as reflected in Kirwan's Elements, for example, the importance of precise terminology, constant need to correct gross indications of unassisted senses and the need to try to attain the same precision as that of algebraic formulas. He may have picked up other ideas from Belsham on language and method: the desirability of explicit definitions, the need to keep the complexity of causal interactions in mind, the need to stick to mono-causal explanations. He may have learnt from Horner that we should avoid the practical men's hasty generalisations and distinguish between limited experience and transitory effects, on the one hand, and permanent regularities, on the other.

He shared with Malthus the 'Newtonian' lesson, a generally accepted view of science as the art of establishing principles from qualified observation, a basis made of universal facts as contrasted with apparent or transitory phenomena, which Ricardo calls 'permanent causes'. He differed from Malthus in emphasising the limits to human knowledge, in mistrusting causal explanations and restricting science to 'general laws'.

\section{Keywords}

Limited Scepticism; Scientific Terminology; Scientific Laws; Causality; Strong Cases; Utility

\section{Ricardo on ethics and political economy}

Ricardo was not a utilitarian. He was instead a critic of utility, consequentialism, selfinterest. His ethics was based on good readings, including Bayle, Montesquieu, Adam Smith and Paley. He had it clear that there are universal moral principles neither dependent on positive religion nor derived from the felicific calculus, 'moral impressions' are the first source of moral judgement, the rational search of happiness is the 'rule of life' whose beneficence is a crucial part.

He assumed that human nature is complex, not governed only by pain and pleasure but also by imagination and desire for sympathy. He was aware that happiness is a complex and unstable condition, and the mirroring relationship between individuals plays an important role.

He endorsed unlimited toleration, believed that good government is secured by representative institutions and a system of checks and balances that makes the interest of those in power coincide with those of the citizens. 
He believed that the science of political economy highlights the general laws regulating the economy. The legislator is free to pursue ends dictated by a sense of justice within the bounds of what is possible. Removing legislation and institutions distorting the market would strengthen the labourers' bargaining power.

Ricardo believed that theodicy is a question without an answer. His cautious attitude vis-à-vis the social question depends on an awareness of the limits to human knowledge. He sided with the poor but with caution dictated by awareness of the additional misery any significant change unavoidably carries.

\section{Keywords}

Ethical Theory; Happiness; Natural Morality; Utilitarianism; Religion and Morality; Limited Scepticism; Theology; Theodicy; Toleration; Just War; Social Justice 